\title{
Enzymes Effect On Performance Characteristics And Nutrients Utilization In Chicken broilers (Gallus Domesticus brizzen ) Fed Gliricidia sepium leaf Meal (Jacq)
}

\author{
A.M.K. Ogungbesan ${ }^{1}$ A.O. Adebayo ${ }^{1}$ A M Akanji ${ }^{1}$ and K.Adeyemi ${ }^{2}$ \\ 1)Animal production department C.A.S Ayetoro O.O.U Ogun state Nigeria \\ 2)National Productivity Centre, Sokoto state office sokoto, Nigeria
}

\begin{abstract}
Ninety six day old broiler chick swere brooded and randomly allocated to four dietary treatments of 24 birds replicated into three groups with eight birds per replicate. Four experimental diets were formulated; the test ingredient is Gliricidia sepium leaf meal. Two of the diets were formulated without enzymes supplementation i.e diet $A$ and diet $B$ while the remaining two treatment were supplemented with (Roxazyme (G2) and Maxigrain). Gliricidia sepium leaf meal was included at the level of $5 \%$ replacement of dietary soyabean meal in diets $B, C$ and $D$. After eight weeks data collected were feed intake, weight gain and body weight changes. Daily feed intake was more significantly $(p<0.05)$ reduced in birds fed control diet. Highest $(P<0.05)$ body weight gain(36.46gd1) and nutrients utilization was observed in birds fed with Maxigrain (diet D) supplement $(p<0.05)$. The best,even better than the control, improvement in the response indices were obtained in birds fed (Maxigrain) diet D. Hence forage Gliricidia sepium meal of 5\% could be included with $0.10 \%$ Maxigrain.
\end{abstract}

Keywords: Broilers,Enzymes, Gliricidia,Performance-characteristics, Nutrients-utilization

\section{Introduction}

The conventional protein feedstuffs for poultry such as soyabean(Glycine max), Groundnut cake(Arachis hypogea), and fish(Pisces) meal are scarce and expensive because they are competed for by humans as food and other industrial uses. The rising cost of finished feed, which is $70-80 \%$ of the cost of production among others, is a major set back.. The prices of such conventional protein feed ingredients such as groundnut cake, soyabean meal and fish meal have soared so high in recent times that it is becoming uneconomical to use them in poultry feeds .[1] There is need,therefore to look for locally available and cheap sources of feed ingredients, particularly those that do not attract competition in consumption between humans and livestock such as Gliricidia for the formulation of balanced ration. Leaf meals do not only serve as protein source but also provide some necessary vitamins, minerals and also some yellow colour of broiler skin,and shank [1]. Leaf meals are gaining acceptance as feed stuff in poultry diet, they are locally available and considered to be non-conventional feeding stuff. The nutrients profile of these leaf meals compare favourably well with some conventional feeding stuffs. Satisfactory performance have been reported of various leaf meal tested in the diet of some classes of poultry birds. Gliricidia sepium is a multipurpose tree legume that is second only to Leucaena leucocephala in worldwide popularity. Gliricidia possess the ability to provide large quantities of high quality forage matter all-year-round as well as the ability to maintain a sustainable environment through nitrogen fixation thus replenishing the soil,though it contains bitter tasting coumarols, cyanogenic glycoside,tannin saponin, and cell wall content that's makes it less usefull for monogasters [2]. Exogenous enzyme supplements (classical feed biotechnological method) are now widely used in poultry diets in an attempt to improve nutrient utilization, health and welfare of birds, product quality and to reduce pollution as well as increase the choice and contents of ingredients at cheaper cost which are acceptable for inclusion in diets [3]. There is need therefore to investigate the effect of these unconventional feed resources on the performance characteristics of broiler.The main objective of the study was to determine the effect of enzymes on performance characteristics and nutrient utilization in broilers fed Gliricidia sepium leaf meal.

\subsection{Study Location}

\section{Materials And Method}

This experiment was carried out at the Poultry unit of the Teaching and Research Farm of College of Agricultural Sciences, Olabisi Onabanjo University, Yewa Campus, Ayetoro, Ogun State. Ayetoro is located in latitude $7^{0} 15^{\mathrm{i}} \mathrm{N}$ Longitude $3^{0} 3 \mathrm{E}$ a deciduous derived savannah zone in Ogun State. Climate sub-humid tropics with an annual rainfall of $963.3 \mathrm{~mm}$ in 74 days with maximum of $29^{\circ} \mathrm{c}$ during the peak of wet season and $34^{\circ} \mathrm{c}$ during the dry season; mean annual relative humidity is $81^{\circ} \mathrm{c}$. Ayetoro lies between 90 and $120 \mathrm{~m}$ above the sea level. The entire area is made up of undulating surface, which is drained majorly by River Rori and River Ayinbo. 


\subsection{Processing Of Test Ingredient}

Fresh, young Gliricidia sepium leaves were harvested, dried under shade for several days, milled to obtain Gliricidia Leaf Meal (GLM) and incorporated into four broiler diets in which soyabean was replaced with Gliricidia Leaf Meal at $0 \%$ (control diet) and 5\% respectively for the other diets. The diets (Table 3.1) was formulated to contain approximately $21.45 \%$ and $20.50 \%$ Crude protein and $2644.36 \mathrm{Kcal} / \mathrm{kg}$ and 2567.53 $\mathrm{Kcal} / \mathrm{kg}$ Metabolizable Energy (ME). The diets (Table 3.2) was formulated to contain approximately $21.59 \%$ and $20.65 \%$ Crude protein and $2675.36 \mathrm{Kcal} / \mathrm{kg}$ and $2553.53 \mathrm{Kcal} / \mathrm{kg}$ Metabolizable Energy (ME).

\subsection{EXPERIMENTAL BIRDS}

A total of 96 day-old broiler chicks (Rock harnicks) was purchased at UNAB Leventis Farm, Abeokuta. The birds were divided into four treatments at 24 birds per treatment. Each treatment was replicated three times at 8 birds per replicate. The feeding trial lasted for eight weeks. Feed and water were supplied $a d-$ libitum. Vaccines against New Castle disease were administered to the birds immediately after hatching and when they were 3 weeks old respectively. The birds were de-wormed adequately, while antibiotics were also given.

\subsection{EXPERIMENTAL DIETS}

Four experimental diets were formulated (Tables 2and 3). Two of the diets were formulated without enzyme supplementation i.e Diet A and Diet B while the remaining two of the diets were formulated with enzyme representation (Roxazyme and Maxigrain) i.e Diet $\mathrm{C}$ and Diet D respectively. The test ingredient (Gliricidia leaf meal) was included at 5\% replacement of dietary soyabean.

\subsection{GROWTH STUDY}

The experimental diets were offered feed and water ad libitum in separate feeders in the morning, and afternoon. Birds in each replicate were weighed at the commencement of the experiment and weekly thereafter. Feed consumption record was kept on weekly basis.

\subsection{METABOLIC STUDIES}

The metabolic studies was carried out between the seventh and eighth week of the feeding trial. Three birds per replicate were put in metabolic cages fitted with mechanism for quantitative feeding and faecal collection . The droppings collected were weighed fresh, dried to constant weight at $100 \%$ and ground before chemical analysis.

\subsection{ECONOMIC ANALYSIS}

The effects of experimental diets on feed cost and economy of feed conversion to body weight were analysed as thus:

1. The cost of dietary ingredients $(\# / \mathrm{kg})$ of each treatment was noted

2. The feed intake per bird was also noted and was used to multiply the cost $/ \mathrm{kg}$ of feed in order to know the cost of feeding a broiler for the period of experiment.

3. The cost $/ \mathrm{kg}$ body weight also calculated by dividing the cost of feeding by the body weight gain $(\mathrm{g})$.

\subsection{CHEMICAL AND STATISTICAL ANALYSIS}

Samples of the test ingredients, diets and excreta were analysed for proximate component using the analytical methods described by [4]. All data obtained were subjected to analysis of variance (ANOVA) using Complete Randomized Design as described by [5].

Table.1; Chemical composition of test ingredient (GLM)

\begin{tabular}{lc}
\hline Composition & \\
GLM (\%) & $(\%)$ \\
\hline & \\
Crudeprotein & 24.38 \\
Etherextract & 1.75 \\
Crudefibre & 12.45 \\
Ash & 11.58 \\
NFE & 49.84 \\
\hline
\end{tabular}


Table2 Percentage Composition of Experimental Starter Diets

\begin{tabular}{lcccc}
\hline Ingredients (\%) & $\begin{array}{c}\text { Diet A } \\
\text { (Control) }\end{array}$ & $\begin{array}{c}\text { Diet B } \\
\text { with GLM }\end{array}$ & $\begin{array}{c}\text { Diet Diet D } \\
\text { GLM with R }\end{array}$ & GLM with M \\
\hline Maize & 45 & 45 & 45 & 45 \\
SBM & 20 & 15 & 15 & 15 \\
GLM & - & 5 & 5 & 5 \\
GNC & 8 & 8 & 8 & 8 \\
Fish meal & 3 & 3 & 3 & 3 \\
Oyster shell & 10 & 10 & 10 & 10 \\
Wheat offal & 11.25 & 11.25 & 11.25 & 11.25 \\
Bone meal & 2 & 2 & 2 & 2 \\
Vit. Premix & 0.25 & 0.25 & 0.25 & 0.25 \\
Methionine & 0.25 & 0.25 & 0.25 & 0.25 \\
Salt & 0.25 & 0.25 & 0.25 & 100.00 \\
Total & 100.00 & 100.00 & 100.00 & \\
Calculated chemical composition & & & 20.50 \\
Crude protein & 21.45 & 20.50 & 20.50 & 3.35 \\
Ether extract & 2.64 & 3.35 & 3.35 & 7.08 \\
Crude fiber & 6.79 & 7.08 & 7.08 & 3.02 \\
Ash & 2.74 & 3.02 & 3.02 & 2567.53 \\
Energy [Kcal/kg] & 2644.36 & 2567.53 & 2567.53 & \\
\hline
\end{tabular}

$\mathrm{GLM}=$ Gliricidia leaf meal, SBM = Soyabean meal, GNC = Groundnut cake,

$\mathrm{R}=$ Roxazyme G2, M = Maxigrain

Table 3. Percentage Composition of Experimental Finisher Diets

\begin{tabular}{|c|c|c|c|c|}
\hline Ingredients (\%) & $\begin{array}{c}\text { Diets A } \\
\text { (Control) }\end{array}$ & $\begin{array}{c}\text { Diets B } \\
\text { with GLM }\end{array}$ & $\begin{array}{l}\text { Diets C } \\
\text { GLM with R }\end{array}$ & $\begin{array}{c}\text { Diets D } \\
\text { GLMwith M }\end{array}$ \\
\hline Maize & 41 & 41 & 41 & 41 \\
\hline SBM & 20 & 15 & 15 & 15 \\
\hline GLM & - & 5 & 5 & 5 \\
\hline GNC & 8 & 8 & 8 & 8 \\
\hline Fish meal & 3 & 3 & 3 & 3 \\
\hline Oyster shell & 10 & 10 & 10 & 10 \\
\hline Wheat offal & 15.25 & 15.25 & 15.25 & 15.25 \\
\hline Bone meal & 2 & 2 & 2 & 2 \\
\hline Vit. Premix & 0.25 & 0.25 & 0.25 & 0.25 \\
\hline Methionine & 0.25 & 0.25 & 0.25 & 0.25 \\
\hline Salt & 0.25 & 0.25 & 0.25 & 0.25 \\
\hline Total & 100.00 & 100.00 & 100.00 & 100.00 \\
\hline \multicolumn{5}{|c|}{ Calculated chemical composition } \\
\hline Crude protein & 21.59 & 20.65 & 20.65 & 20.65 \\
\hline Ether extract & 2.65 & 3.36 & 3.36 & 3.36 \\
\hline Crude fiber & 6.49 & 6.78 & 6.78 & 6.78 \\
\hline Ash & 2.78 & 3.06 & 3.06 & 3.06 \\
\hline Energy $[\mathrm{Kcal} / \mathrm{kg}]$ & 2675.36 & 2553.53 & 2553.53 & 2553.53 \\
\hline
\end{tabular}

$\mathrm{GLM}=$ Gliricidia leaf meal, $\mathrm{SBM}=$ Soyabean, $\mathrm{GNC}=$ Groundnut cake, $\mathrm{R}=$ Roxazyme $\mathrm{G} 2, \mathrm{M}=$ Maxigrain

\section{Results And Discussion}

Tables 1-3 show test forage ,starters, and finshers composition respectively while in Table 4,final weight and body weight gains of birds reduced with inclusion of Roxazyme G2 (diet C), though there were better weight gains with Maxigrain (diet D) supplement $(\mathrm{p}<0.05)$. The observed improvement in the weight gains of the enzyme supplemented diet D (Maxigrain) may be explained by the fact that exogenous enzymes supplement the digestive enzymes of monogastric animals by aiding the breakdown of non-starchy polysaccharides, protein and antinutritional factors thereby increasing their nutritional value [6] Birds placed on diet D (5\% GLM with Maxigrain) was observed to have highest feed intake per day. This may be due to action of enzyme cellulase that breakdown cellulose for more energy and releases locked nutrients [6]There was significant difference in feed conversion ratio of the experimental diets. Improvements in the efficiency of utilization of poultry diets have been reported as a result of enzymes supplementation of feed [6] In all, it appeared that birds on diet D (5\% GLM with Maxigrain) had better performance even than the control diets[7] . 
Table 4 Effect of Gliricidiasepium Leaf meal supplemented with enzyme on the Performance

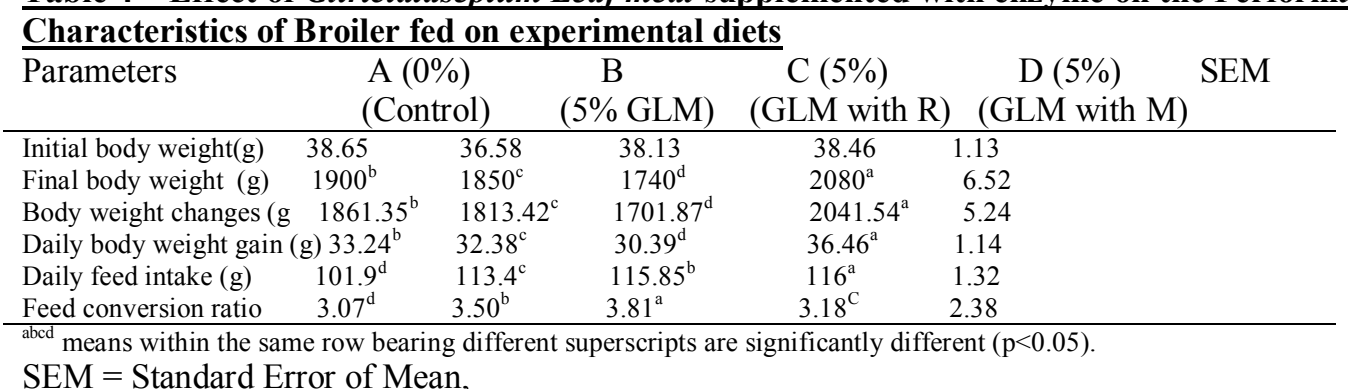

Crude protein digestibility(Table 5$)$ was significantly $(\mathrm{P}<0.05)$ affected by dietary treatment birds on diet $\mathrm{D}(5 \%$ GLM with Maxigrain) had superior digestibility of protein compared to the other diets. Diet A (Control) had the least protein digestibility $(69 \%)$. Crude fiber digestibility was also significantly $(\mathrm{P}<0.05)$ influenced by dietary treatment. These results were in accordance with the findings of [8] who reported an improvement in the nutrient digestibility due to enzyme addition. Ash digestibility and Lipid digestibility were also significantly $(\mathrm{P}<0.05)$ influenced by the dietary treatment[8],[7].

Table 5; Effect of Gliricidiasepium Leaf meal supplemented with enzyme on the Nutrient Digestibility of the experimental diets

\begin{tabular}{lcccccc}
\hline A & \multicolumn{2}{c}{ A } & B & C & C & D \\
Parameters & $($ Control $)$ & $(5 \%$ GLM $)$ & $(5 \%$ GLM with R) & $(5 \%$ GLM with M) & SEM \\
\hline Crude protein (\%) & $69^{\mathrm{d}}$ & $72^{\mathrm{c}}$ & $75^{\mathrm{b}}$ & $78^{\mathrm{a}}$ & 0.88 \\
Lipid (\%) & $92^{\mathrm{b}}$ & $91^{\mathrm{b}}$ & $92^{\mathrm{b}}$ & $94^{\mathrm{a}}$ & 1.00 \\
Fiber (\%) & $55^{\mathrm{c}}$ & $52^{\mathrm{d}}$ & $62^{\mathrm{b}}$ & $64^{\mathrm{a}}$ & 1.00 \\
Ash (\%) & $60^{\mathrm{b}}$ & $60^{\mathrm{b}}$ & $61^{\mathrm{a}}$ & $63^{\mathrm{a}}$ & 1.00 \\
Dry matter & $78^{\mathrm{c}}$ & $72^{\mathrm{d}}$ & $79^{\mathrm{b}}$ & $80^{\mathrm{a}}$ & 0.67 \\
\hline
\end{tabular}

${ }^{\text {abcd }}$ means within the same row bearing different superscripts are significantly different $(\mathrm{p}<0.05)$.

$\mathrm{SEM}=$ Standard Error of Mean

Table 6 shows the cost effectiveness of the different dietary treatment. Diet 1 was the most expensive in terms of cost per $\mathrm{Kg}$. Addition of GLM reduced the cost of feed per $\mathrm{kg}$. Feed cost per $\mathrm{kg}$ reduced with increasing concentration of GLM from diet A to diet D. However, the cost of Roxazyme increased the cost per kilogram of diet containing it. Nonetheless, supplementing the diet D with Maxigrain per kilogramme of diet resulted in cheaper cost per kilogramme weight gain compared to other diets. This outcome in diets D, favours inclusion of the enzyme Maxigrain,[8],[7] since the desire of every investor is to maximize profit and productivity at the least cost. Hence, Maxigrain has practical advantages (Maxigrain ${ }^{\circledR}$ is blend of the most relevant digestive enzymes to serve the purpose of optimizing the cost \& performance of birds. The following are active ingredients in Maxigrain ${ }^{\circledR}$ enzyme and their effect on target substrate; $\alpha$-amylase:Hydrolyzesglycosidic bonds from starchy material liberating metabolizable sugar.;Xylanase:Acts on residues of arabinoxylans and mannans,; $\beta$-Glucanase:Hydrolyzes beta glucans,;Exo-Cellulase:Hydrolyzesglycosidic bonds to liberate metabolizable sugar,;Pectinas:Hydrolyzes pectic acid,;Protease:Acts on proteins to liberate peptides and amino acids,;Phytase:Hydrolyzesphytic acid to release phosphorus,;Lipase:Complements indigenous lipases to digest extra fat added to the feed.Hence, benefits of Maxigrain ${ }^{\circledR}$ enzyme ,optimizing the use of non-conventional feed ingredients, Improving weight gain,Improve litter quality and dropping consistency,improving feed conversion ratio (FCR),improves egg production and shell quality andreduces levels of DCP incorporation in the feed substantially) and is strongly recommended for use in broiler diets..Per adventure there is apparent lack of response to enzyme supplementation,reasons advanced by [9] include the following; the likelihood/possibilty of the diet being fed be of extremely good quality and allow the animals to perform close to their genetic potential.,that enzymehas the incorrect mains pecificity (amylases,pectinases, $\beta$ glucanases,arabinoxylases,cellulases, hemicellulases,,acidproteases, alkalineproteases, phytases, esterases,lipases)a nd or attendant supplementary activity for the substrate,denaturation of the enzyme before the diet is consumed,or supplementation of the diet with wrong enzyme,variation within an ingredients in the concentration or activity of proteinaceous antinutrients to the enzyme,variation in the quality of feed ingredients,animal stage of growth /maturity.It must be emphasized ,however according to [10] that for commercial use, exogenous enzymes must be able to survive the rigours of feed processing (Temperature,Pressure, and Moisture)and the in-hospitableG.I.T.enviroment.Not only do these enzymes have to survive the fluctuations of $\mathrm{pH}$ and proreolytic attack by enzymes, but they also have to operate in these conditions at a meaningful rate in order to accomplish the neccesary degrees of digestion of the intended substrate but lastly, application of enzymes allow the animal to plant phosphorus and depend less on inorganic $\mathrm{P}$ thereby reducing $\mathrm{P}$ environmental pollution[10]. 
Table 5Economic Analyses of feeding broiler on experimental diet supplemented with Gliricidiasepium leaf meal, enzyme Maxigrain and Roxazyme.

\begin{tabular}{cccc} 
Treatment & Cost of feeding & Cost per kg body weight & Cost per kg feed \\
\hline 1 & 8315.04 & 250.15 & 81.60 \\
2 & 8845.20 & 273.17 & 78.00 \\
3 & 9082.64 & 298.87 & 78.40 \\
4 & 9071.20 & 248.80 & 78.20 \\
\hline
\end{tabular}

Cost per kilograms feed, cost per kilograms weight gain of Broiler bird fed different dietary treatment

\section{Conclusion and recommendation}

Based upon the findings in this study, it is recommended that 5\% Gliricidiasepium leaf meal and $0.10 \%$ Maxigrain can be incorporated into broiler diets respectively. Further research on various level of inclusion of GLM is needed to confirm these findings and to elucidate the mechanism which are responsible for the better performance of broiler chickens on diet with enzyme (Maxigrain) .Since Maxigrain is specifically design for MAXImum efficient use of GRAIN based ration

\section{References}

[1] B.OEsonu,., F.C. Iheukwumere, T.C. Iwuji, N. Akanu and O.H. Nwugo, Evaluation of Microdesmispuberulaleaf meal as feed ingredient in broiler starter diets. Nig. J. Anim. Prod.,30(2003)3-8

[2] . A. JSimons,.And, J.L. Stewart Gliricidia sepium - a multipurpose tree legume. In: Forage Tree Legumes in Tropical Agriculture (R.C Gutteridge and H.M Shelton, eds)Walling Ford, UKCABI,. (1994) Pg30-48

[3] M,R Bedford)Exogenous enzyme in monogastric nutrition-their current value and future benefits,Anim Feed Sci\& Tech 86 ,.(2000) $1-13$

[4] A.O.A.COfficial method of Analysis (16 ${ }^{\text {th }}$ Ed) Association of Official Analytical Chemists, Washington DC, (1995)

[5]. S.A.S Statistical Analysis Software. SAS.Ints.Inccary N.Y, (2002).

[6] M Chot,Enzymes for the feed industry, past, present and future. World's poultry Science Journal 6(2)( 2006)5-15

[7]. A.M Ogungbesan, Awoola, O.J.,Adeleke, G.A.andAdenugba,A. The Effect of Enzymes on Blood Constituents and Minerals Utilization in Broilers Fed Gliricidiasepium (Jacq)Epizootiologyand Animal Health in West African 9(2013) (In press)

[8] S.GAdemola,..O.O,Egbewande.I.E,Lawal,.A.T,Isah, andS.M Kuranga,Effect of Roxazme $\mathrm{G}^{\circledR}$ and Maxigrain ${ }^{\circledR}$ on Performance ,Egg quality, Cost benefit and Haematological parameters of laying hens fed Wheat offal,Corn bran and Brewers Dry Grain diets .International J. of Poultry Science 11(1) (2012)33-38

[9] TAcamovicCommercial application of enzyme technology for poultry production. World poultry Science journal57 ,.(2001)1-18

[10] M,RBedford, Mechanism of action and potential environmental benefits from the use of feed enzymes Anim Feed Sci\& Tech(1995)145-155 